\section{Protective Mimicry}

In NATURe, No. 126, for 28th ult., at p. 436, M. G. Pouchet is recorded to have stated in a paper read before the Academy of Sciences, first, that prawns accommodate their colour to that of surrounding objects; second, that removing their eyes prevents this change of colour.

Of the truth of the first assertion I presume there is no doubt ; but of the second I should much like to learn further, for when we speak of Protective Mimicry in all the lower forms of life, we do not assume that there is any ratiocinative mimicry. Yet if this power of protective mimicking in the prawn is dependent upon eye-sight, i.e., upon the power of conveying impressions upon the optic nerve to the brain, does it not cease to be "mimicry" as generally understood, and pass into the order of mental volition? If so, how vast and interesting is the consideration !

I hope that Mr Darwin, Mr. Wallace, or some other of your scientific contributors will enlighten through your columns

March 31 IGNORAMUS

\section{¿RANIAL MEASUREMENTS}

W

HILE engaged in the investigation of another matter, I was induced to make a series of cranial measurements, and these I wish to record under the impression that they may be of use in the hands of some future worker, though by themselves they are not of much value.

The measurements were made at Wakefield, in Yorkshire, during 1868-9, and are those of the working-classes of the town and neighbourhood. Careful inquiry was made as to the birthplace and parentage of each subject, and no measurements are given save of those belonging to the basin of the rivers Calder and Aire. The type of the people is pre-eminently Saxon, and the results may therefore be taken as pretty accurately representing the configuration of the crania of modern Yorkshire.

Attached are also the average height and weight for each decade, and a calculation of the average cephalic index.

The measurements of the head were taken by large calJipers, and are simply the greatest bi-parietal and occipitofrontal diameters, and the measurement of the face is from the tip of the chin to the root of the hair on the forehead.

The average cephalic indices of the whole would show men to be slightly more brachio-cephalic than women (by 75), while the result of the whole is decidedly eurycephalic.

The cephalic indices of each decade of age would lead us to believe that dolicho-cephalic people have a better chance of life than the brachio-cephalic people, unless we believe that the form of the cranium alters between thirty and forty years of age.
The entire table leads me to believe that there is not much value to be placed in such cranial measurements for the purposes of racial distinction ; certainly not in isolated skulls; for see the curious variations of measurement in couples of the same sex taken from the same decade, as shown in the table below:-

\begin{tabular}{|c|c|c|c|c|}
\hline Age. & $\begin{array}{l}\text { Length of } \\
\text { head. }\end{array}$ & $\begin{array}{l}\text { Breadth of } \\
\text { head. }\end{array}$ & Cephalic Index. & $\begin{array}{l}\text { Difference in } \\
\text { Cephalic Index. }\end{array}$ \\
\hline Years. & Inches. & Inches. & & \\
\hline 3 & $\begin{array}{l}7.25 \\
6^{\circ} 25\end{array}$ & $\begin{array}{l}5.25 \\
5.50\end{array}$ & $\begin{array}{l}72^{2} 4 x \\
88^{\circ} \text {, }\end{array}$ & $15 \times 59$ \\
\hline$x_{4}^{3}$ & 7.12 & 5.37 & $75^{\circ} 42$ & 8.55 \\
\hline$x_{4}$ & $7 \times 2$ & $6 . \infty$ & $84.27\}$ & \\
\hline $\begin{array}{l}25 \\
28\end{array}$ & $\begin{array}{l}7.37 \\
6.62\end{array}$ & $\begin{array}{l}5.75 \\
55^{\circ} 75\end{array}$ & $\begin{array}{l}78.026 \\
86.86\end{array}$ & 8.84 \\
\hline $3^{2}$ & 5.87 & $\begin{array}{l}5.15 \\
6.12\end{array}$ & $x 0426$ & $26^{\circ} 12$ \\
\hline 35 & $\begin{array}{l}7.00 \\
8.00\end{array}$ & $\begin{array}{l}5.75 \\
6.75\end{array}$ & $\left.\begin{array}{r}82.74 \\
84^{\circ} \cdot 3\end{array}\right\}$ & $\begin{array}{l}2012 \\
10.80\end{array}$ \\
\hline 43 & $8 \% 0$ & 6.00 & $\begin{array}{l}04.371 \\
75 \%\end{array}$ & 3509 \\
\hline 47 & 700 & 775 & Iro*7I\} & $357^{1}$ \\
\hline 52 & $\begin{array}{l}7775 \\
7.25\end{array}$ & $\begin{array}{l}600 \\
6 \% 0\end{array}$ & $\left.\begin{array}{l}77^{4} 42 \\
82^{4} \cdot 6\end{array}\right\}$ & 534 \\
\hline 65 & 700 & 5.50 & 79.577 & $0^{\circ} 2 \mathrm{Y}$ \\
\hline 69 & $7 \times 2$ & 6.25 & & \\
\hline
\end{tabular}

For the purpose of contrasting the results $I$ have obtained in the measurements of height and weight, I add a translation of Quetelet's tables :-

\begin{tabular}{|c|c|c|c|c|c|}
\hline \multicolumn{3}{|c|}{ MEN. } & \multicolumn{3}{|c|}{ WOMEN. } \\
\hline Age. & Size. & Weight. & Age. & Size. & Weight. \\
\hline Eirth & Ft. In. & Lbs. & Birth & Ft. In. & Lbs. \\
\hline I & $\begin{array}{ll}1 & 7 \\
2 & 307\end{array}$ & $22^{\circ} 04^{\circ}$ & $I$ & $23^{*} \times 360$ & $\begin{array}{l}20^{\circ} 497 \\
\end{array}$ \\
\hline 2 & $27^{\circ} 377$ & $26^{\circ} 44^{8}$ & 2 & 26.708 & 25.425 \\
\hline 3 & $=9.858$ & $29^{\circ} \times 15$ & 3 & $=945^{6}$ & $27^{\circ} 44^{\circ}$ \\
\hline 4 & 30.692 & $33^{\circ} 214$ & 4 & 2 II.020 & $3 \mathrm{I} \cdot 253$ \\
\hline 5 & 32776 & 36.807 & 5 & $3 \quad 2.340$ & $34^{\circ} \times 62$ \\
\hline 6 & $3 \quad 4964$ & $39^{\circ} 70^{\circ}$ & 6 & 34620 & 36.905 \\
\hline $\begin{array}{l}7 \\
8\end{array}$ & $\begin{array}{r}3 \\
37^{\circ} 779^{\circ} \\
\end{array}$ & $\begin{array}{l}44^{\circ} 433 \\
49^{\circ} \circ 6 \mathrm{I}\end{array}$ & $\stackrel{7}{8}$ & $\begin{array}{ll}3 \cdot & 7.152 \\
3 & 8.832\end{array}$ & $\begin{array}{l}40^{\circ} 644 \\
43^{\circ} 683\end{array}$ \\
\hline 9 & $4 \quad 0.307$ & $53^{\circ} 094$ & 9 & $3 \times x \cdot 26_{4}$ & $49^{\circ} 45^{8}$ \\
\hline Io & $4 \quad 2473$ & 57.569 & Io & $4 \quad 1.128$ & 53425 \\
\hline IX & $4 \quad 4484$ & $6 x \cdot 38 x$ & II & $42 \times 96$ & 57.855 \\
\hline 12 & 45504 & $68^{\circ} 324$ & 12 & $4 \quad 4236$ & 67320 \\
\hline$I_{3}$ & $4 \quad 7 \div 34$ & 77.846 & 53 & $\begin{array}{ll}4 & 6 \\
35_{4}\end{array}$ & $75^{\circ} \circ 79$ \\
\hline $\mathrm{I}_{4}$ & 4 10.543 & 89.262 & $x_{4}$ & 48.964 & 83.973 \\
\hline I5 & $5 \times 378$ & IO2' 288 & $x_{5}$ & $410^{\circ} 068$ & 91026 \\
\hline I6 & $5 \quad 3.386$ & $\operatorname{Ir} 7^{\circ} 672$ & 16 & $4 \mathrm{YI}^{\circ} \mathrm{O} 2$ & $97^{\circ} 94^{6}$ \\
\hline$x 7$ & $5 \quad 5748$ & $126^{\circ} 510$ & 17 & $5 \quad I \times 76$ & 108.175 \\
\hline 18 & 56.684 & I 35 or 8 & 18 & $5 \quad r{ }_{488}$ & II $70^{\circ} 03$ \\
\hline Ig & 5. $7^{*} \geq 64$ & I $39^{\circ} 55^{8}$ & $x 9$ & & (not given) \\
\hline 20 & 57356 & $43 \cdot 26 x$ & 20 & $5 \quad x \cdot 800$ & $\times 20^{\circ} 030$ \\
\hline 25 & $\begin{array}{ll}5 & 7 \\
788\end{array}$ & $150^{\circ} 512$ & 25 & 52076 & I $2 x \cdot 397$ \\
\hline 30 & 57788 & ${ }^{1} 5 \times 857$ & 30 & $5 \quad 2 \times 60$ & $12 \mathrm{r} \cdot 529$ \\
\hline 40 & $5 \quad 7^{\circ} 440$ & ${ }_{151} \cdot 6_{58}$ & 40 & $5 \quad I^{\prime} 212$ & 124.857 \\
\hline $5 c$ & $5 \quad 5094$ & $148.66 \mathrm{r}$ & 50 & $5 \quad 0^{\circ} 43$ & $\times 28.826$ \\
\hline 60 & $5 \quad 4524$ & $x_{44} \cdot 3^{6} 3$ & $6 a$ & $4 x \times 673$ & I $25^{\circ} \circ 34$ \\
\hline 70 & $5 \quad 3.888$. & 138.919 & 70 & $4 \pi I^{\prime} 60_{4}$ & $x 18.400$ \\
\hline 80 & 53.404 & I $34^{\circ} 93^{\circ}$ & 80 & $4 \mathrm{II}^{\circ} 294$ & II2.55I \\
\hline
\end{tabular}

MALES

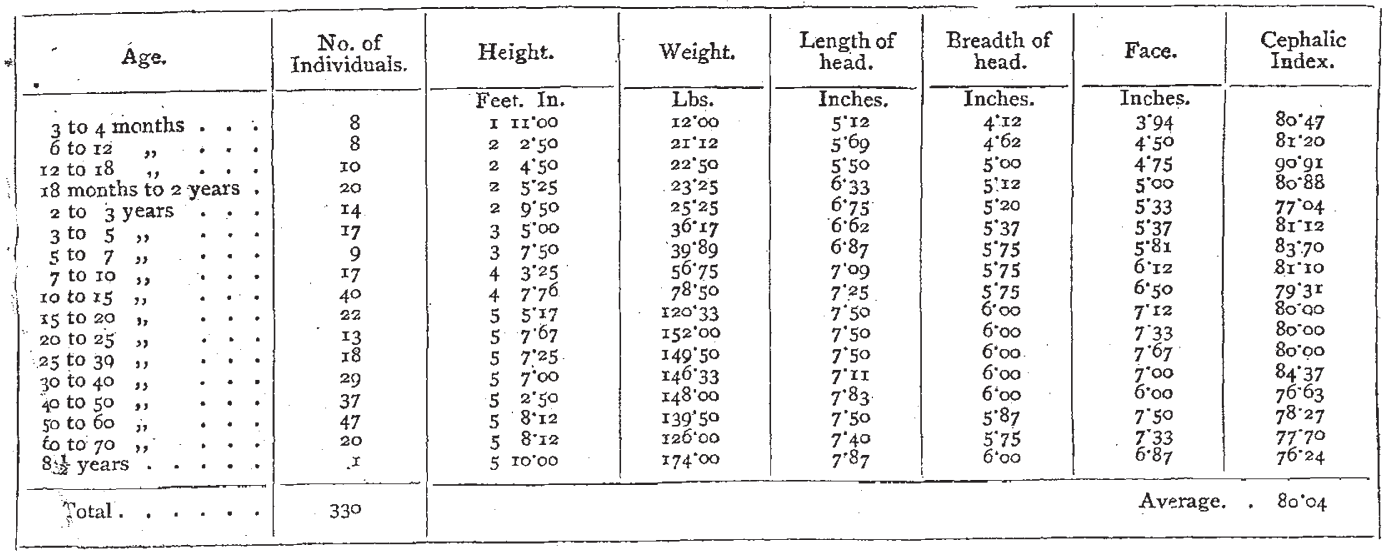


FEMALES

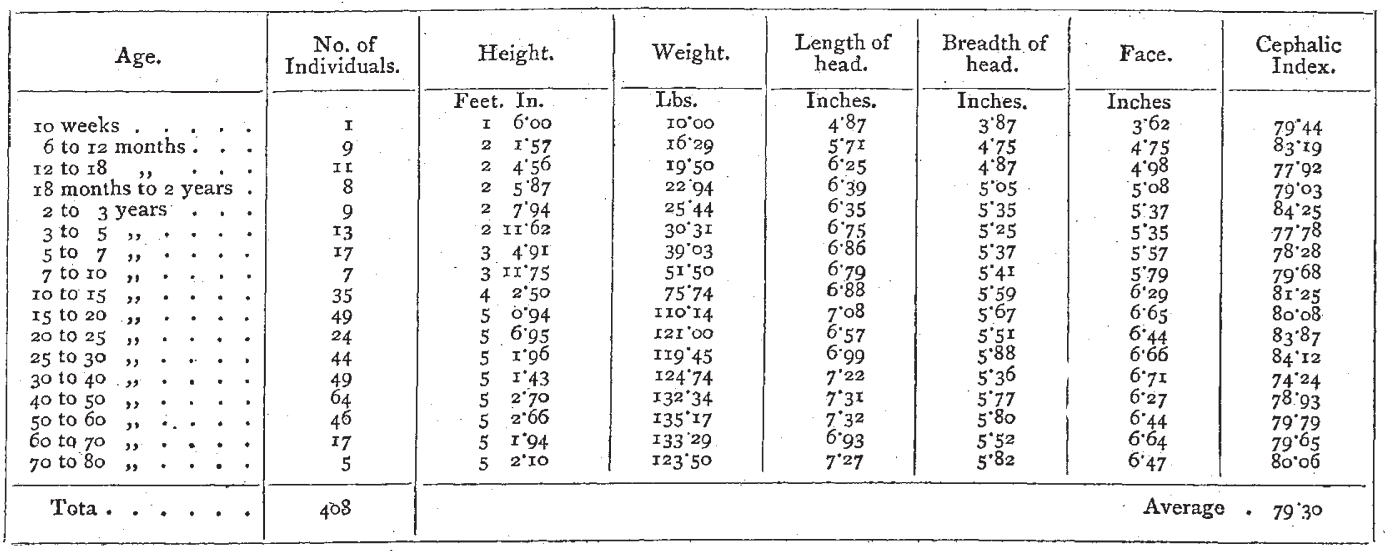

LAWSON TAIT

\section{ONE SOURCE OF SKIN DISEASES}

$\mathrm{O}^{\mathrm{s}}$

BSCURE affections of the skin. of the face of men especially are well known to specialists to be widely spread. They are commonly classed as ekzema, and while causing great discomfort especially at night, show nothing, or almost nothing, to the eye, if the patient be otherwise in pretty good health. Skin specialists frequently ask patients whether they have been using any new sort of soap, but no one seems hitherto to have traced any distinct communication between soap and this troublesome disease.

As I have been able pretty distinctly to do so in reference to myself, probably a brief notice of the facts may not be out of place in NATURE, where it is likely to be of more popular benefit than if committed to the pages of a medical journal, in which the inferences of "mere laymen" are not greatly reputed. It is a fact but very little known to the multitude of both sexes who use the "Prime Old Brown Windsor Soap" of the perfumers' shops, that by far the largest proportion of it is manufactured from "bone-grease." Few more beautiful examples of chemical transformation are to be found in the whole range of chemical manufacture than this one. At one end of a long range of buildings we find a huge shed heaped up with bones, usually such as are of little value to the bone-turner or brush-maker, in all stages of putrefaction as to the adherent or inherent portions of softer animal matter attached to them, the odour of which is insupportable.

These are crushed and ground to a coarse powder, exposed to the action of boiling water under pressure, sometimes of steam, until the grease and marrow are extracted.

We need not here pursue the subsequent treatment of the rest of the material from which bone glue and "patent isinglass" are prepared, the latter of which we often eat in the soups and jellies of the pastrycooks, and finally to the " bone dust," or phosphate of lime, nearly free from animal matter," which is produced for the use of the assayer and the china manufacturer, \&c., as well as for other purposes in the arts.

But let us follow up the bone-grease, which is of a dark tarry brown colour, and of an abominable odour.

By various processes it is more or less defæcated, bleached, and deodorised, and is separated into two or three different qualities, the most inferior of which goes to the formation of railway or other machinery greases, and the latter is saponified, and becomes, when well manufactured, a hard brown soap, still, however, retaining an unpleasant smell. It is now, after being remelted, strongly perfumed, so that, like the clothes and persons of the magnates of the Middle Ages, its own evil odour is hidden by the artificial perfume.

This is the "Fine Old Brown Windsor Soap" of most of our shops. The natural brown colour of the grease gives it the right tint in the cheapest way, without the colouring by caramel, which was the original method of manufacture.

Like all other things, there are cheap and dear Windsor soaps; and for the production of the former little is done beyond saponifying and casting into blocks or bars. Were wể to rely upon the many experiments that have been made as to the degree of elevation of temperature at which putrescent or other contagious matter is deprived of its morbific power, we might conclude that boiling and saponifying had made this hitherto putrescent grease innocuous.

It seems, however, more than doubtful that such is the fact in this case, for the soap thus made seems to be capable of communicating skin diseases when rubbed on the face for use in shaving.

But another promoter of irritation is not unfrequently also found. Whether it be that it is more profitable to the soapmaker to have a liberal proportion of the finer particles of the ground bone made up with the soap, or that these are difficult to separate completely, the fact is that bars of this "Brown Windsor Soap" are to be bought containing a rich mixture of those small sharp angular fragments of bone which before boiling was putrid. When a piece of such soap is rubbed hard to a man's face, the skin is more or less cut and scored by these bony particles held in the soap like emery in a head "lap" and thus the skin is placed in the most favourable state to absorb whatever there may be of irritant, or contagious, or putrid in the soap itself. The existence of the bone fragments is easily verified by solution of the soap in water or alcohol, and examination of the undissolved particles with a lens; and I can readily, if need be, send you a piece of such soap for examination.

Now, without occupying too much of your space, I may just state that I have while using such shaving soap thrice suffered from ekzema of the face. On the first occasion I derived no benefit from treatment by the two most celebrated dermal surgeons in London, and at last the disease went away of itself after giving up shaving for a time. I had by me a quantity of this brown soap, and through inadvertence took to using it again, for a time without effect ; but when dry and hot weather came, with it came a recurrence of the skin disease, which also again after some months of discomfort, went away. Curious to make sure 